\title{
Planning the Teacher as in Loco Parentis for an Effective School System
}

\author{
Mohammed, M. O. B. (Ph.D) \\ Department of Educational Management, Faculty of Education, \\ Lagos State University, Ojo, Lagos State, Nigeria \\ Gbenu, J. P. (Ph.D) \\ Department of Educational Management, Faculty of Education, \\ Lagos State University, Ojo, Lagos State, Nigeria
}

Lawal, R.O.

Department of Educational Foundations and Management, School of Education, Michael Otedola College of Primary Education, Noforija-Epe, Lagos State, Nigeria

\section{Doi:10.5901/mjss.2014.v5n16p318}

\section{Abstract}

\begin{abstract}
In loco parentis, a Latin phrase, meaning in place of parent, is used to describe any other guardian or individual serving the role of a child's parent. At the school level, the use of the expression is now well pronounced with the teacher saddled with this responsibility. Beyond academic activities which the teacher is expected to execute in the school, all other roles in the school for the teacher are geared towards ensuring the 'total' development of the child, including morals. This makes the job of the teacher a herculean one, considering children from different backgrounds characterized with different attitudes. As a result of this, the teacher needs various experiences from different fields like psychology, sociology, human relations and even economics supported with various theories of the child to function effectively, otherwise the shoes of in loco parentis may be too big for him to wear. Thus, the paper suggests continuous training to keep abreast with the challenges of playing the role of a parent.
\end{abstract}

\section{Introduction}

The term in loco parentis, a Latin expression, means "in the place of a parent", or "instead of a parent" as described by the Oxford Dictionary of Rhymes (2006). It is used to describe the responsibility of a teacher towards the pupils. Literarily, according to Anderson (1996), it means, "in the place of a parent". Alexander and Alexander (1998) describe the term as "a legal doctrine describing a relationship similar to that of parent to a child. It refers to an individual who assumes parental status and responsibilities for another individual, usually a young person, without formally adopting that person".

Described by the Oxford Dictionary of Rhymes (2006) as "a legal responsibility of a person or organization to take on some of the functions and responsibilities of as parent", it is applied in two separate areas of the law according to the Dictionary.

First, it allows institutions such as colleges and schools to act in the best interests of the students as they fit, although not allowing what would be considered violations of the students' civil liberties. Second, this doctrine can provide a non-biological parent to be given the legal rights and responsibilities of a biological parent if they have held themselves out as the parent.

Whilst a child is in a teacher's care, some of the privileges of the natural parent are transferred to the teacher so that he or she may carry out his or her duties. In return therefore, the teacher must assume certain responsibilities and recognize that both legal and moral obligations rest upon him or her in every aspect of the work.

In loco parentis as a concept, is by far, the most common usage term, relating teachers to students. For hundreds of years in the expression of Hunt (2002), "the English common-law concept shaped the rights and responsibilities of public school teachers: until the late nineteenth century, their legal authority over students was as broad as that of parents".

Taking root in colonial American schools, in loco parentis was an idea derived from English common law according 
to Hunt (2002), who traces the history of in loco parentis. In his description, he said that the colonists borrowed it from the English ideal of schools having not only educational but also moral responsibility for students. With this duty, went the equivalent of parental authority. The idea especially suited the puritanical values of the colonists, and after the American Revolution, it persisted in elementary and highs schools, colleges and universities.

Thus, it is evident that the teacher has to serve as a parent for the children under his care in the school. Beyond academic activities, so are other challenges before the teacher to ensure a disciplined and 'complete' child. In line with these enormous challenges, the paper focuses on the roles of the teacher as in loco parentis in schools and what qualify him to be in this position among other challenges he faces.

\section{The Teacher as a Replacement Parent}

Hunt (2002) spells out or suggests some roles or duties the teacher is expected to play while acting as a parent. These are as follows.

1. Plan school trips carefully. School's procedure must always be followed strictly in this area making sure that the teacher has adequate staff ratios, making sure that any volunteer is trustworthy.

2. If a teacher is concerned about a child's welfare, the teacher must speak to the teacher in charge of child protection. The teacher must record concerns, remembering that any disclosure must be reported, hence the need to maintain confidentiality.

3. A teacher must refer any child not collected by his or her parent to social services after school hours.

4. A teacher is not obliged to administer medicines to pupils, although the teacher may be asked to oversee children's use of asthma pumps, for example. The teacher must keep a list of pupils who have medical conditions. Unwell children should not be in school, and parents must provide contact details in case of emergencies.

5. Corporal punishment is unlawful. If children endanger themselves or others, the teacher can use 'reasonable force' to restrain them, but must tread with caution as his actions could be legally challenged and could risk being assaulted.

6. In the worst case, if a teacher is accused of negligence, he must seek advice. As a teacher's employer, the school has vicarious liability and the teacher should not be held responsible where he or she has maintained a professional standard of supervision.

\section{Teacher Characteristics}

In line with the various duties saddled the teacher as the parent within the school system, he must possess certain features to be able to discharge effectively. In line with this, McCormick (2006) identifies twelve teacher characteristics based on a large-scale study conducted in the United Kingdom. These characteristics have been put into four 'clusters': professionalism, thinking/reasoning, expectations and leadership. Table 1 contains these features:

Table 1: Teacher characteristics

\begin{tabular}{|c|c|l|}
\hline Cluster & Characteristics & \multicolumn{1}{|c|}{ Description } \\
\hline \multirow{4}{*}{ Professionalism } & Commitment & $\begin{array}{l}\text { Commitment to doing everything possible for each student and enabling all students to be } \\
\text { successful }\end{array}$ \\
\cline { 2 - 3 } & Confidence & Belief in one's ability to be effective and to take on challenges \\
\cline { 2 - 3 } & Trustworthiness & Being consistent and fair; keeping one's word \\
\cline { 2 - 3 } Thinking/reasoning & Respect & Belief that all individuals matter and deserve respect \\
\hline \multirow{3}{*}{ Expectations } & Conceptical thinking & Ability to think logically, break things down and recognize cause and effect \\
\hline & Drive for improvement & Ability to identify patterns and connections, even when a great deal is present \\
\cline { 2 - 3 } & Information seeking & Drive to find out more and get to the heart of things; intellectual curiousity \\
\hline \multirow{3}{*}{ Leadership } & Initiative & Drive to act now and to anticipate and pre-empt events \\
\cline { 2 - 3 } & Flexibility & Ability and willingness to adapt to the needs of a situation and change tactics \\
\cline { 2 - 3 } & Accountability & $\begin{array}{l}\text { Drive and ability to set clear expectations and parameters and hold others accountable for } \\
\text { performance }\end{array}$ \\
\cline { 2 - 3 } & Passion for learning & $\begin{array}{l}\text { Drive and ability to support students in their learning, and to help them become confident } \\
\text { and independent learners. }\end{array}$ \\
\hline
\end{tabular}

Source: Adopted from McCormick, 2006 
Table 1 emphasizes more on the role of the teacher as a replacement parent in schools for pupils.

The changing role of teachers in the words of Hamalainen and Jokela (2005) "calls for new knowledge and capabilities". Recent research on teaching and learning appear to give particular emphasis on a deep knowledge of the subject to be taught and an understanding of, and ability, to use a range of pedagogical approaches. Teachers are also expected to have knowledge of the social development of children and of management function (Hamalainen and Jokela, 2005).

McCormick (2006) still adds three features of an excellent teacher.

First, high quality teachers have a passion in their lives and a deep regard for their students, that is, they love their students. Second, they lead challenging and demanding lives that set high standards and inspire their changes. In other words, they are prophetic. Third, they are always fully engaged in the mystery of life, with hearts and minds full of wonder and awe, open to learn new things and understand new realities.

Katz (1998) and Reiger and Stang (2000) state that a teacher need to be "curious, imaginative, empathetic, interesting, friendly and hardworking in order to be effective in the classroom, thereby creating a learning environment that enhances and strengthens the learning disposition of the students".

In his own fashion, Brain (1998) describes the best teacher through a number of questions: "what are the qualities that combine to create an excellent, memorable teacher? Why do some teachers inspire students to work three times harder than they normally would, while others inspire students to skip class? Why do students learn more from some teachers than others"? If one aspires to become a better teacher, these are important questions in Brain's (1998) words. Indeed, it could be inferred that he identified the issue of emphasis on teaching as focusing on the four essential qualities that distinguish exceptional teachers - knowledge, communication skills, interest and respect for students.

In describing the qualities expected of a good teacher, Carelton's (1992) proverbial assertion exposes who a good teacher should be. According to him:

the teacher must have the energy of a harnessed volcano, the efficiency of an adding machine, the memory of an elephant, the understanding of a psychiatrist, the wisdom of Solomon, the tenacity of a spider, the patience of a turtle trying to cross the highway in a rush-hour traffic, the decidedness of a general, the diplomacy of an ambassador, the financial acumen of a stock and bonds wizard, and finally to always remember that teachers teach not by words but mostly by percept and example.

Thus, the teacher must continue to train him or herself on the job to cope with the challenge of the job especially relating to academic and care of the pupils.

\section{Conclusion}

For as long as the goals of the school depend on the skills and acumen of the head of the school, the teacher is at the centre of the goal realization. Beyond academic activities, the school should be seen as the second home of the child, whose well-being will not be handled by the head of the school, but the teacher. Hence the teacher must be caring, subtle in approach to issues with the child, act as an adviser, and above all, play the role of the child's parent. He needs various experiences from different fields like psychology, sociology, human relations and even economics supported with various theories of the child to function effectively, otherwise the shoes of in loco parent may be too big for him to wear. Though the challenges are enormous, he needs constant training on the job to be able to cope and keep abreast of ways of handling child.

\section{Recommendations}

Based on the suggestion of a multi-disciplinary approach to handling school children, the following recommendations are put forward.

1. Employment of qualified (education) degree teachers in secondary schools especially at the Senior Secondary School level where adolescence stage and its characteristics set in.

2. Re-orientation of the teachers on the job with the need to adopt multi-disciplinary approach towards improving students' quality of lives.

3. Necessity for a counseling unit should be emphasized in schools.

4. Encouragement of teachers to go on series of training especially those that centre around the upbringing of the child, beyond specialized training on their fields. 


\section{References}

Alexander, K. and Alexander, M. (1998). Teachers' rights and freedoms. American public school law. Belmont, CA: Wadsworth Anderson, T. H. (1996). The movement and the sixties. NY: Oxford University press

Brain, M. (1998). Emphasis on teaching. What is good teaching? Raleigh, N. C.: BYG Publishing Inc.

Carelton, O. (1992). Teacher quality. In J. A. Majasan (ed). The teachers' profession: A Manual for Professional Excellence. Lagos: Spectrum.

Hamalainen, S. and Jokela, J. (2005). Teacher and students as active learners. A case study of one Finnish school's method of defining, interpreting and operationalizing the term 'active learning'. University of Jyvaskyla, Department of Teacher Education.

Hunt,. V. (2002). In loco Parentis? TES magazine, 1 (2), 1 - 4

Katz, L. G. (1998). What should young children be doing? NY: American Educator.

McCormick, P. (2006). There's no substitute for good teachers. US Catholic, 6 (6), 101

Oxford Dictionary of Rhymes (2006). UK: Oxford University press. 